Ann. Génét. Sél. anim., I974, 6 (2), 219-226.

\title{
BREEDING GOALS FOR BEEF CATTLE
}

\author{
E. P. CUNNINGHAM \\ The Agricultural Institute, \\ Department of Animal Breeding and Genetics, \\ Dunsinea, Castleknock, Co. Dublin (Ireland)
}

\section{SUMMARY}

Specialised beef breeds can be used as :

I. both sire and dam in commercial beef production;

2. component of the dam in commercial beef herds ;

3. sire line for crossing on dairy or commercial beef cows.

Evidence from crossbreeding trials suggest that the first role will be a declining one. Field data indicate that a beef $x$ dairy cow may be the best commercial beef dam. The requirements of a beef sire line are analysed in economic terms, and the potential contribution of a sire line used for crossing on dairy cows is calculated. For fairly reasonable conditions, it is shown that this can double the economic value of the genetic merit from an average insemination in the dairy cow population.

There are several quite distinct roles which specialised breeds of beef cattle can play, depending on the structure of the cattle population in which they are used. They can function as :

I. Both sire and dam in commercial beef production. This is the situation in the great beef populations of the world - as in Argentina, the U. S. A., Australia and in parts of France.

2. Component of the dam in commercial beef herds. This is generally the situation in Ireland and Britain, where the commercial beef cow is commonly a crossbred.

3. Sire line for crossing on dairy cows.

4. Sire line for crossing on commercial beef cows.

Each of these roles calls for its own set of specifications in a beef breed. In order to examine the goals which a breed should set itself, it is necessary to consider which one or combination of these roles it is expected to perform.

( $)$ This article has been presented as an invited report at the Commission on Animal Genetics of E. A. A. P., Meeting of Vienna, September 23-28th, I973. 


\section{I. - USE OF BEEF BREEDS IN PURE FORM}

Only four countries in Western Europe have substantial numbers of specialised beef cows. Their approximate populations of beef and dairy cows are as follows.

$\begin{array}{lcccc} & \text { Italy } & \text { France } & \text { Breat } \\ & - & - & - & - \\ \text { Dairy cows, millions...... } & 3.2 & 8.4 & 3.3 & \text { I.3 } \\ \text { Beef cows, millions ...... } & 0.8 & 2.6 & \mathbf{I} .5 & 0.7\end{array}$

Two quite different patterns in the breed background of these beef cows are apparent.

It is generally recognised in Britain and Ireland that commercial beef production from the beef breeds in their pure form is not economic. The traditional suckler cow is a beef $\times$ dairy cross. This practice has a sound base in genetic theory, in that the whole complex of reproductive and mothering traits that make for efficient beef dams are likely to show considerable heterosis. However, it takes a particular type of population structure to provide a steady flow of such replacement females for the beef herd. The Irish and British cow populations are so structured, in that each contains about $30 \mathrm{p}$. IOO of beef cows and $70 \mathrm{p}$. IOO of dairy cows. A proportion of the dairy cows are usually bred to beef bulls. So there is available throughout the population a steady supply of beef $x$ dairy heifers. The movement of these heifers from dairy to beef herds is not difficult, because both kinds of herds are found in all grassland areas.

Accidents of history and geography have dictated quite different structures in France and Italy and in the great beef producing countries overseas. In the U. S. A., for instance, the beef cow population is located mainly in the western states, far from the main dairy areas. In addition, there has been a tradition of highly specialised dairying, with beef crossing little practised. For these reasons, beef producers have had to breed their own replacement females. The result has been a beef industry based on pure Hereford and Angus cattle - not because this is technically the best way to use these breeds - but largely through force of circumstances. Recent experiments (GREGORY, I970; CUNDIFF, I973) have clearly demonstrated the advantage of crossbred females in this kind of population. Cows which are crosses between the traditional beef breeds are $15 \mathrm{p}$. Ioo more productive than the same breeds in pure form. Productivity here is measured as weight of calf weaned per cow per year. In the same terms, a further Io $\mathrm{p}$. Ioo can be gained from heterosis in the calf, $i . e .$, by having the sire of the calf from a breed different to the dam. The total effect of systematic crossing is therefore about $25 \mathrm{p}$. Ioo.

This evidence is leading to increasing interest in the use of planned crossing programmes for beef cow populations. In populations that breed their own replacement females, this must be in the form of cyclical crossbreeding of some kind. So the role of the specialised beef breeds in their pure form as commercial beef cows is likely to be a declining one. 


\section{II. - BEEF BREEDS AS COMPONEN'TS OF THE COMMERCIAI, BEEF COW}

The only product of a suckler cow is her weaned calf. The value of this product is the probability that she produces a live calf in the first instance, multiplied by the weight of calf weaned. Since about $85 \mathrm{p}$. Ioo of the feed input to the cow and calf unit goes to the cow, the main cost involved is the cow's annual feed requirement. This can be fairly adequately described as a function of cow body weight. A reasonable measure of the economic utility of a commercial beef cow would therefore be the weight of calf weaned per Ioo $\mathrm{kg}$ of cow weight. The ways in which the cow contributes to this goal are shown in figure $I$.

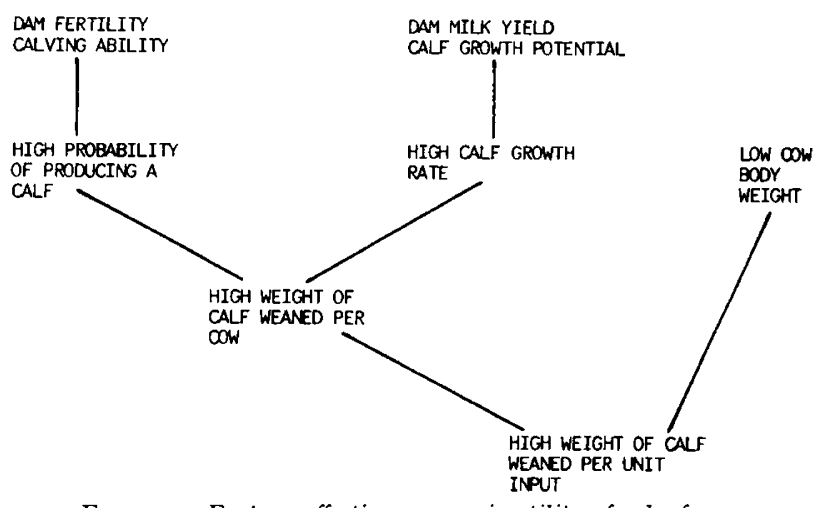

FIG. I. - Factors affecting economic utility of a beef cow

FIG. I. - Facteurs influençant l'intérêt économique d'une femelle allaitante

There is only one point in this complex where the aims are in conflict. That is between the requirement for small cow body size in combination with high calf growth potential. Since mature body weight and growth rate are highly correlated genetically, it may be difficult to pursue these two aims simultaneously. In order to measure their relative importance, it is necessary to reduce them to the common denominator of money.

The maintenance requirement of an extra Ioo $\mathrm{kg}$ of cow body weight can be calculated from, for example, the work of NeviLLE and McCulLough (I969) as about I225 Mcal ME per year. If the cow receives two thirds of her feed as grazed grass and most of the rest as conserved grass, the cost per Mcal. ME in Irish conditions is about $0.5 \mathrm{p}$. This gives an annual maintenance cost of about $£ 6.00$ per Ioo $\mathrm{kg}$. If weanling calves are valued at $45 \mathrm{p}$. per $\mathrm{kg}$ liveweight, then it takes an extra $13 \mathrm{~kg}$ of calf weaned to cover the increased maintenance cost of the dam. Both feed costs and calf prices will be different in other countries, but these differences are likely to require more rather than less calf output to compensate for cow feed requirements.

Most of the American evidence on this shows a lower gain in calf weight per 
IOo $\mathrm{kg}$ increase in cow weight. SingH et al. (I970) found $4.7 \mathrm{~kg}$; NEVILLE (I962) found $7.0 \mathrm{~kg}$; while KNOx (I957) found smaller cows giving higher calf weight per unit of cow weight than bigger cows. These studies all concern essentially purebred Herefords. The British MLC field recording programme gives some information across breeds. 'Their results are given by KILKENNy and STOLLARD (I973), from whose paper the following graph is reconstructed.

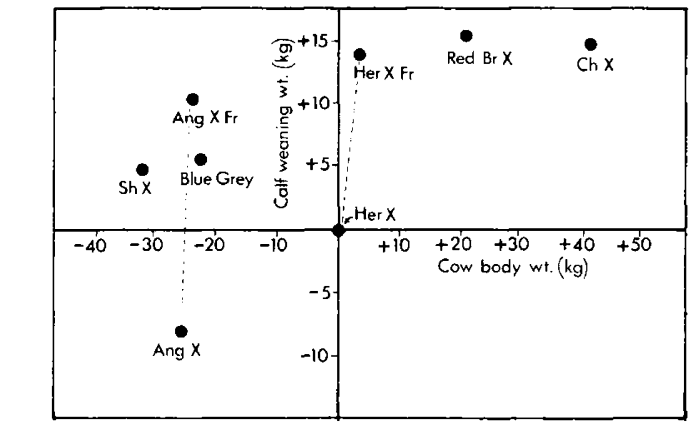

FIG. 2. - Relationship of calf weaning weight to cow body weight

(data of KILKENNY and STOLLARD, I973)

FIG. 2. - Liaison entre le poids du veau au sevrage et le poids vif de la mère

Two conclusions may be drawn from these figures. The first is that it pays to have a dairy component in the cow : Angus $\times$ Friesian cows give almost $20 \mathrm{~kg}$ more calf weaned than Angus type cows, while both types of cow have the same bodyweight. The second conclusion is that cows sired by the large breeds (Red breeds + Charolais) compare well with other beef-type cows, but not so favourably with beef $X$ dairy type cows. Thus Charolais cross cows weighed more than $40 \mathrm{~kg}$ heavier than Hereford $\times$ Friesian cows, but produced $5 \mathrm{~kg}$ less in calf weight per Ioo $\mathrm{kg}$ of cow. Note that all these comparisons use the Hereford type cow as a refeerence base.

The overall conclusion, therefore, is that while larger cows produce larger calves, the increase in calf output does not compensate for the increased cow maintenance requirement. However, the non-feed costs in a beef herd tend to be per cow and not per unit of cow weight, and so will favour larger cows. In addition, the increased slaughter value of larger cows will offset some of the increased growth and maintenance costs incurred. The feed requirement needed to produce one extra $\mathrm{kg}$ of liveweight and to maintain it for the normal life of a beef cow, say, eight years, amounts to about roo Mcal ME. In Irish conditions this costs approximately $50 \mathrm{p}$. The slaughter value of the extra $\mathrm{kg}$ of liveweight is about $30 \mathrm{p}$. The net cost per $\mathrm{kg}$ is therefore $20 \mathrm{p}$, , or $£ 20.00$ per Ioo $\mathrm{kg}$. If the cow produces five calves, this averages $£ 4.00$ per calf, so that even when account is taken of the cull value of the cow, the maintenance cost is likely to exceed the value of the correlated gain in calf weaning weight. On balance, therefore, it appears that smaller cows are more economic as beef dams, and that the larger beef breeds, including the Charolais, should not normally be a component of the commercial beef cow. 


\section{III. - BEEF BREEDS AS SIRE LINES}

This is where the larger beef breeds have the greatest advantage. Whether it is as crosses out of dairy cows or out of commercial beef cows, their progeny are expected to be profitable, single-purpose beef animals. What are the factors that make beef animals profitable ? There are essentially three, and profitability is roughly their product. They are :

I. Probability of survival.

2. Growth rate.

3. Proportion of meat in the carcasse.

There are, of course, other factors too, but they are either of small economic importance or vary little between animals or breeds. To put these three factors in perspective, it is necessary again to use the common denominator of money.

The question of survival is largely concerned with the birth of the calf. Mortality after the perinatal period tends to be low and random. There are, however, well established breed and bull differences in the rate at which their calves die or cause trouble at birth. Suppose two bulls or two breeds differ by I p. Ioo in the perinatal mortality of their calves. Valuing calves at $£ 60$, this represents a charge of 60 p. per head on each surviving calf. In addition, one must take account of the increased management costs on a cow which loses a calf. These are hard to quantify, but it might be reasonable to put them at $£$ Io, or Io p. per surviving calf. Breeds orbu lls which differ by I p. Ioo in calf mortality will differ by about twice that rate in difficult calvings (Federatie K. I. Nederland, r970). Valuing the distress to both cow and farmer at $£$ I5 means that the two difficult calvings are costing $£ 30$, or $30 \mathrm{p}$. per surviving calf. So one can say, in very round figures, that a I p. Ioo difference in calf mortality, with an associated difference of $2 \mathrm{p}$. Ioo in calving difficulties, costs about $£$ I.oo per calf born. This calculation, of course, does not allow for the fact that this cost is only a theoretical charge on all calves, and must in practice be carried by a single animal.

Valuing growth potential is somewhat easier. If two animals differ by I p. roo in growth rate, the faster growing one will in a given time achieve a I p. Ioo higher weight. If cattle are marketed at around $500 \mathrm{~kg}$ this amounts to $5 \mathrm{~kg}$ liveweight. At present Irish prices, this extra liveweight has a gross value of $£ \mathrm{I}$.80. Its net value, after subtracting feed cost, is about $f$ I.oo.

A beef carcass contains about $70 \mathrm{p}$. Ioo of meat. If the carcass is valued solely on its meat content, and its price is $62 \mathrm{p}$. per $\mathrm{kg}$, this values the meat it contains at approximately $88 \mathrm{p}$. per $\mathrm{kg}$. A difference of I p. Ioo in meat content between two $250 \mathrm{~kg}$ carcasses is therefore worth $2.5 \mathrm{~kg}$ at $88 \mathrm{p}$. or $£ 2.20$ per animal.

The relative economic values of a $\mathrm{I}$ p. Ioo improvement in calf mortality, growth rate and meat content are therefore approximately as follows.

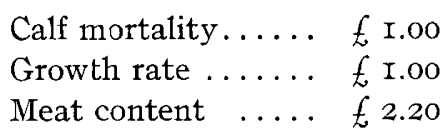


These figures have implications first for the choice between breeds, and secondly for the selection goals which should guide improvement within beef breeds.

It is very difficult to obtain a precise comparison of breeds for these traits. This is partly because precise experiments with cattle are very expensive, and so not very numerous ; partly because with less precise, but less costly field data it is often difficult to disentangle breed differences from other factors; and partly because the samples of the breeds involved are different in different countries. With all these qualifications, three hypothetical beef crossing breeds are compared in table r.

TABLE I

Comparison of three hypothetical beef breeds for the economic value of their crossbred progeny

Comparaison entre trois races bovines à viande du point de vue de la valeur économique de leur descendance croisée

\begin{tabular}{|c|c|c|c|}
\hline & Breed A & Breed B & Breed C \\
\hline & \multicolumn{3}{|c|}{ Technical Performance } \\
\hline Calf mortality $(\%) \ldots \ldots$ & 5 & 3 & 2 \\
\hline Relative growth rate $(\%) \ldots$ & 112 & 106 & 100 \\
\hline \multirow[t]{2}{*}{ Meat Content $(\%) \ldots \ldots \ldots$} & 71 & 72 & 70 \\
\hline & \multicolumn{3}{|c|}{ Economic cost or benefit per animal $(\mathfrak{f})$} \\
\hline Calf mortality $(\%) \ldots \ldots \ldots$ & -3.00 & -1.00 & 0.00 \\
\hline Relative growth rate $(\%) \ldots$ & +12.00 & +6.00 & 0.00 \\
\hline Meat Content $(\%) \ldots \ldots \ldots$ & +2.20 & +4.40 & 0.00 \\
\hline TOTAL $\ldots \ldots \ldots \ldots \ldots$ & +11.20 & +9.40 & 0.00 \\
\hline
\end{tabular}

These figures approximate to what one might expect from Charolais (A), Limousin (B) and traditional British breeds (C) under Irish conditions of production, though it should be emphasised that these synthetic figures are contradicted by experience with these particular breeds in some populations. The largest difference of $£$ Ir.20 amounts to about 8 p. Ioo of the gross value of a beef animal.

These figures can also be evaluated per insemination fairly simply, since in normal circumstances all the crossbred progeny of a beef sire line are slaughtered. Given an $86 \mathrm{p}$. Ioo net reproductive rate in the population, and an $8 \mathrm{p}$. Ioo discount rate, each insemination will result in the equivalent of 0.68 net progeny at the time of the insemination. The present value per insemination of breed $\mathrm{A}$ over breed $\mathrm{C}$ is then $£ \mathrm{II} .20 \times 0.68=£ 7.6$.

The systematic use of breed differences of this order is essential in a beef cow population. In a dairy cow population, the position is less clear, though there are also large advantages to be gained. To illustrate this, I wish to compare three strategies for a population of dairy cows. Net reproduction is assumed to be $86 \mathrm{p}$. IOo, the discount rate is again taken as $8 \mathrm{p}$. Ioo and cows are presumed to last for 4 lac- 
tations. If the dairy bulls are selected at a rate of $\mathrm{I}$ in 5 on progeny test, their average breeding value for dairy production will be about $3 \mathrm{p}$. Ioo of the mean. Let us say this is worth $f 3.00$, which it is in Ireland. If their beef breeding value is taken as a base, then assume that it is possible to provide a breed or line of specialised beef bulls which have a beef breeding value of $+£$ ro.oo for overall beef merit. Three strategies can then be compared.

I. Breed all cows to dairy bulls.

2. Breed 20 p. Ioo to beef bulls.

3. Breed 40 p. Ioo to beef bulls.

The number of discounted dairy or beef progeny equivalents per dairy insemination for each strategy is given in table 2 (CunNINGHAM, I973).

TABLE 2

Number of discounted dairy and beef progeny equivalents per insemination for differents levels of beef crossing

Nombre d'équivalents-descendants actualisés pour le lait ou la viande par insémination $\grave{a}$ différents niveaux de croisements pour la viande

\begin{tabular}{c|c|c}
\hline \hline \multirow{2}{*}{$\begin{array}{c}\text { Beef crossing } \\
(\%)\end{array}$} & \multicolumn{2}{|c}{ Discounted progeny equivalents per insemination } \\
\cline { 2 - 3 } & Dairy & Beef \\
\hline & & \\
\hline 20 & 0.89 & 0.71 \\
40 & 1.11 & 0.72 \\
& 1.48 & 0.73 \\
\hline
\end{tabular}

\section{TABLE 3}

Economic value of genetic merit in average insemination for varying levels of beef crossing

Valeur économique de la supériorité génétique moyenne transmise par insémination pour divers niveaux de croisement à viande

\begin{tabular}{c|c|c|c|c}
\hline \hline $\begin{array}{c}\text { Beef crossing } \\
(\%)\end{array}$ & \multicolumn{2}{|c|}{$\begin{array}{c}\text { Financial value per insemination } \\
\text { of genetic merit from }\end{array}$} & $\begin{array}{c}\text { Total value per } \\
\text { insemination } \\
(\mathfrak{f})\end{array}$ \\
\hline & $\begin{array}{c}\text { Dairy merit of } \\
\text { dairy bulls }\end{array}$ & $\begin{array}{c}\text { Beef merit of } \\
\text { dairy bulls }\end{array}$ & $\begin{array}{c}\text { Beef merit of } \\
\text { beef bulls }\end{array}$ & \\
\hline 0 & & & & \\
20 & 2.67 & 0 & 1.36 & 2.67 \\
40 & 2.67 & 0 & 2.72 & 5.39 \\
\hline
\end{tabular}

If $\mathrm{K}$ is the proportion of beef crossing, $\mathrm{D}_{d}$ and $\mathrm{D}_{b}$ the discounted progeny equivalents per dairy insemination, $D_{b}^{\prime}$ the discounted progeny equivalents per beef insemination, $\mathrm{M}_{d}$ and $\mathrm{M}_{b}$ the cash value of the breeding merit of dairy bulls for 
dairy and beef production, and $\mathrm{M}_{b}^{\prime}$ the corresponding figure for beef bulls for beef production, then the present financial value of the genetic merit of an average insemination in each case is

$$
(\mathrm{I}-\mathrm{K}) \mathrm{D}_{d} \mathrm{M}_{d}+(\mathrm{I}-\mathrm{K}) \mathrm{D}_{b} \mathrm{M}_{b}+\mathrm{K} \mathrm{D}_{b}^{\prime} \mathrm{M}_{b}^{\prime}
$$

This is made up of three components as shown in table 3 .

Thus, with systematic crossing of a certain proportion of dairy cows to beef bulls the average value of an insemination, in net current terms, can be increased by I02 p. IOo. This means that the amount of beef crossing in European dairy cow populations is likely to increase. This in turn will increase the demand for and benefit from high performing specialised lines of beef crossing bulls.

Reçu pour publicalion en mars 1974.

\section{RÉSUMÉ}

\section{POSSIBILITÉ D'UTILISATION DES RACES BOVINES A VIANDE}

Les races à viande spécialisées peuvent être utilisées :

I. soit comme reproducteur, mâle et femelle, dans les troupeaux commerciaux de vaches allaitantes ;

2. soit comme composante de la femelle dans les troupeaux commerciaux de vaches allaitantes;

3. soit comme souche paternelle de croisement avec des vaches traites ou allaitantes.

Les essais de croisements laissent apparaître que la première orientation va progressivement diminuer. Les données recueillies en ferme montrent qu'une vache croisée race laitière $\times$ race à viande pouvait constituer le meilleur type commercial de femelle allaitante. Les exigences d'une souche mâle à viande pour le croisement terminal sont analysées en termes économiques et la contribution potentielle d'une telle souche utilisée en croisement sur des vaches traites est calculée. Dans des conditions courantes on montre qu'un tel croisement peut doubler la valeur économique moyenne du progrès génétique attendu par insémination réalisée dans la population laitière.

\section{REFERENCES}

CUNDIFF L. V., I973. Effects of Heterosis in Hereford, Angus and Shorthorn Cattle. U. S. Meat Animal Research Centre. Beef Cattle Research Progress Report, I I-22.

Cunningham E. P., 1973. The Discounted Gene Flow Method. Arbeitstagung des Anschusses für

Genetisch. Statistiche Methoden in der Tierzuchtung, Biberach.

Federatie K. I., Nederland. JaArverslag K. I., 1970. Wageningen.

Gregory K. E., 1970. Hybrid Vigour in Beef Cattle. Massey University Sheep-Farming Annual, 237-249.

KilkenNy J. B., Stollard R. J., r973. Bodyweight in suckler cows and its relationship to calf performance. Brit. Soc. Anim. Prod. Meetings, Harrogate.

KNox J. H., r957. The Interrelationships of Type, Performance and Carcass Characteristics. $J$. Anim. Sci., 16, 240-248.

Neville W. E., I962. Influence of Dam's Milk Production and other factors on 120 and 240 Day Weight of Hereford Calves. J. Anim. Sci., 21, 315-320.

Neville W. E., McCullough M. E., 1969. Calculated Energy Requirements of Lactating and Nonlactating Hereford Cows. J. Anim. Sci., 29, 823-829.

Singh A. R., Schalles R. R., Smith W. H., Kessler F. B., i97o. Cow Weight and Preweaning Performance of Calves. J. Anim. Sci., 31, 27-30. 